\title{
CONTRACT FARMING, AGRICULTURE PRODUCTIVITY AND POVERTY REDUCTION: EVIDENCE FROM TEA ESTATES IN VIET NAM
}

\author{
Anh Tru Nguyen, Janet Dzator and Andrew Nadolny*
}

\begin{abstract}
Interest in contract farming is increasing because of its potential as an alternative channel for linking producers to international markets. However, there is limited knowledge on contract farming of tea production in Viet Nam, especially in more inaccessible provinces where tea production plays an important role in generating employment, improving livelihood and reducing poverty. In the present paper, the impact of contract farming on productivity is reviewed in Pho Tho province, a major tea production area that has not been the focus of any other studies. Using survey data, an analysis is conducted on the factors affecting tea productivity and the impact of contract farming on tea productivity in the province. The results indicate that the impact of factors on tea productivity is ambiguous. They also indicate that technical efficiency of tea production of contracted farmers is higher than that of other types of farmers by almost 5 per cent and that contract farming has a positive influence on tea productivity in the province. Because of different climatic conditions, the results from this study are not generalizable across Viet Nam, but they can be applied in the Northern midlands and mountainous areas.
\end{abstract}

JEL classification: C31, D24, Q12

Keywords: contract farming, Phu Tho, poverty reduction, tea productivity, Viet Nam

Anh Tru Nguyen (email: AnhTru.Nguyen@uon.edu.au), Janet Dzator (email: janet.dzator@newcastle.edu. au) and Andrew Nadolny (email: andrew.nadolny@newcastle.edu.au) are from Newcastle Business School, Faculty of Business and Law, The University of Newcastle, New Space, Level 6, 409 Hunter Street, Newcastle NSW 2300, Australia. 


\section{INTRODUCTION}

Tea production generates employment, improves income for small farm households and contributes towards poverty reduction in the rural areas of Viet Nam. Tea products from Viet Nam are exported to more than 100 countries and territories around the world (Khoi and others, 2015). By 2014, about 40 per cent of the tea production in Viet Nam was traded between producers and enterprises through contracts (ActionAid, 2015).

Located in the Northern midlands and mountain area of Viet Nam, Phu Tho province is comprised of 277 commune-level administrative units, which includes 218 mountainous communes and 72 extremely poor communes. At the end of 2016, the rate of poor and near poor households in this province was 10.51 per cent and 8.03 per cent, respectively, and the average income per capita was $\$ 1,454.8$ (Phu Tho Statistics Office, 2017). Among the provinces of Viet Nam, Phu Tho is ranked third in terms of production and fourth in terms of planted area of tea (Department of Agriculture and Rural Development in Phu Tho province, 2015).

In Phu Tho province, linkages between enterprises and farmers in tea production have developed recently. Obviously, there are several factors affecting tea productivity, such as weather, tea varieties, production and harvest techniques, fertilizers and chemical applications. Previous studies have mostly focused on the determinants of technical efficiency of tea production in Viet Nam. Contract farming is increasingly used by tea farmers in Viet Nam, but there is limited knowledge on the effects it has had on tea productivity, especially at the provincial level. The present paper contains a review of the impact of contract farming on tea productivity and the factors affecting tea productivity in general in Phu Tho province.

The specific reasons for selecting tea farming and Phu Tho province are as follows. First, the production of tea features largely in national policies aimed at poverty reduction, employment generation and income improvement for farm households. Second, Phu Tho province is a significant Vietnamese tea producing region. Finally, Phu Tho province faces particular challenges in efforts to improve tea production, such as low yield, overdependence on chemicals, poor coordination between producers and enterprises and lack of owned brands for tea products. It is hoped that this study will increase local knowledge and contribute to efforts aimed at tackling those issues.

The rest of this paper is organized as follows. The second section includes a review of what is known about the link between contract farming and improved productivity for farmers. Poverty, income and tea production of Viet Nam is discussed in the third section. Research methods are presented in the fourth section. The fifth section contains a discussion on the results and the sixth section includes the conclusion and policy implications. 


\section{CONTRACT FARMING AND PRODUCTIVITY IN AGRICULTURE: AN OVERVIEW}

The review of empirical evidence presents differing conclusions on the effects of contract farming on productivity of agricultural products, as discussed below.

Paul and others (2004) examine productivity, economies, and efficiency in agriculture in the United States of America. Although contracts are found to have no strong impacts on those factors, lower contract levels are less efficient than contractintensive entities, implying that there are competitive pressures on small farms in terms of improving their productivity in a contract. In a similar study, Ramaswami and others (2005) analyse efficiency and distribution in contract farming of Indian poultry growers. Their findings indicate that technology and management practices of contracted growers have improved because of standardization of production practices in contracts.

Further support for contract farming is provided by Birthal and others (2008), who explored the relationship between farms and markets through contract farming in the dairy sector of India. They conclude that contract farming contributes towards improving milk yield and reducing production costs because of the advantages small households have by using family labourers and in disposing of milk. Setboonsarng and others (2008) assess the impact of contract farming on rural poverty and farm household income with rice contracts in the Lao People's Democratic Republic. Their research shows that contract farmers obtain higher productivity and improve rice varieties compared to independent ones. Saigenji and Zeller (2009) investigate the impact of contract farming on productivity and the income of farmers in tea production in Moc Chau district, Son La province, Viet Nam. Their findings indicate that contracted farmers gain higher technical efficiency compared to independent ones. Similarly, Begum and others (2012) assess contract farmers in the poultry sector in Bangladesh and their level of efficiency. Their results show that contract farming is a feasible alternative for improving efficiency at the farm level because of technological transfer from integrators to producers. Similar to the findings of Begum and others (2012), Ajao and Oydele (2013) have conducted a study on economic efficiency of contract farming in the tobacco sector in Oyo state, Nigeria, which shows that contract farming can create opportunities for farmers to obtain the maximum output by improving the efficiency of certain resources. Velde and Maertens (2014) research the influence of contract farming on rice production in Benin. Their results indicate that rice productivity of contracted households is higher than that of independent ones because of larger planted areas and intensification in rice cultivation. A study by Kalimangasi and others (2014) examines the contribution of contracts in cocoa production to the livelihood of small farmers in the United Republic of Tanzania. 
Their findings indicate that participation of farmers in contract farming can lead to an increase in production quantity.

Other studies do not provide such clear support for contract farming. Miyata and others (2009) examine the influence of contract farming on the income of farmers in the production of apples and green onions in China. Their conclusions regarding the effects of contract farming on the productivity of apples and green onions are controversial. Specifically, contracted apple producers gain a higher yield compared to non-contracted households because of technical assistance and specialized inputs provided by packers. In contrast, the yield of contracted green onion growers is lower than that of independent producers. A study by Ngoc and others (2014) entails investigating production efficiencies of contracted and independent farmers in tea production in Thai Nguyen and Phu Tho provinces, Viet Nam. Their findings show that there is no difference in statistical significance of technical coefficients between contracted and non-contracted farmers.

\section{SITUATION OF POVERTY, INCOME AND TEA PRODUCTION OF VIET NAM}

\section{Poverty}

Viet Nam made great strides in its efforts to the achieve the Millennium Development Goals. Notably, the rate of Vietnamese inhabitants who live below the national poverty line, declined from 58.1 per cent to 7.1 per cent between 1993 and 2015. Although poverty has decreased sharply, adverse economic events and natural disasters have increased because of climate change and environmental degradation. In addition, about three quarters of the population are classified as near poor or in living in the lower middle-income bracket (United Nations, 2016).

The number of poor households in Viet Nam has declined sharply, by four percentage points to 5.8 per cent in 2016 from 9.8 per cent in 2013. In 2016, the rate of poor households was three times higher in rural areas than in urban areas. Between 2013 and 2016, the rate of poor households throughout the country trended lower. In 2016, the rate of poor households in Viet Nam was the highest in the Northern midlands, at 13.8 per cent, and the lowest in the South-East region, at only 0.6 per cent (table 1). 
Table 1. Rate of poor households in Viet Nam (percentage)

\begin{tabular}{lcccc}
\hline \multicolumn{1}{c}{ Country and areas } & $\mathbf{2 0 1 3}$ & $\mathbf{2 0 1 4}$ & $\mathbf{2 0 1 5}$ & $\mathbf{2 0 1 6}$ \\
\hline Whole country & 9.8 & 8.4 & 7.0 & 5.8 \\
Urban areas & 3.7 & 3.0 & 2.5 & 2.0 \\
Rural areas & 12.7 & 10.8 & 9.2 & 7.5 \\
Red River Delta & 4.9 & 4.0 & 3.2 & 2.4 \\
Northern midland and mountainous & 21.9 & 18.4 & 16.0 & 13.8 \\
area & & & & \\
North Central and Central coastal & 14.0 & 11.8 & 9.8 & 8.0 \\
area & & & & \\
Central Highlands & 16.2 & 13.8 & 11.3 & 9.1 \\
South East & 1.1 & 1.0 & 0.7 & 0.6 \\
Mekong River Delta & 9.2 & 7.9 & 6.5 & 5.2 \\
\hline
\end{tabular}

Source: General Statistics Office of Vietnam (2018).

The number of people undernourished in Viet Nam is presented in figure 1.

Figure 1. Number of people undernourished in Viet Nam

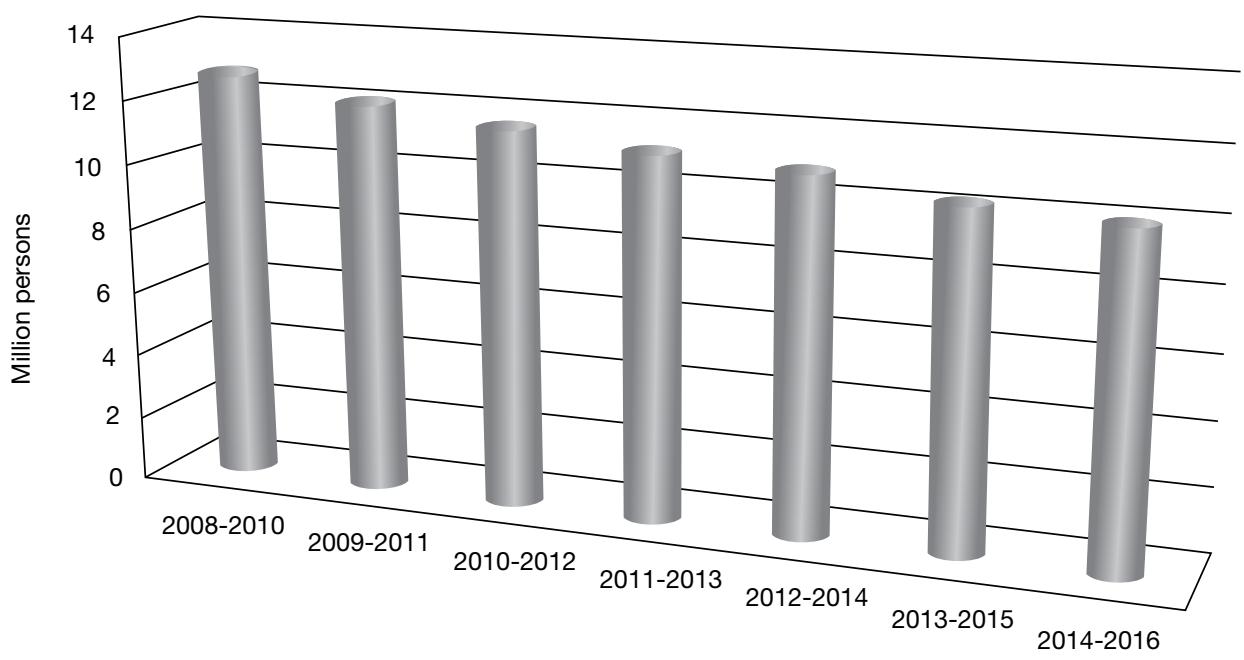

Source: FAO (2018). 
The number of undernourished people in Viet Nam declined from 12.7 million during the period 2008-2010 to 10 million during the period 2014-2016. While this outcome is representative of the significant effect of national food security measures on poverty reduction (figure 1), the country's efforts to alleviate poverty remains strong with specific targets and strategies, many of which involve agriculture, which potentially can affect the majority of the population.

\section{Income}

Annual gross domestic product (GDP) per capita of Viet Nam is presented in figure 2 .

Figure 2. Annual gross domestic product per capita of Viet Nam (2010-2016)

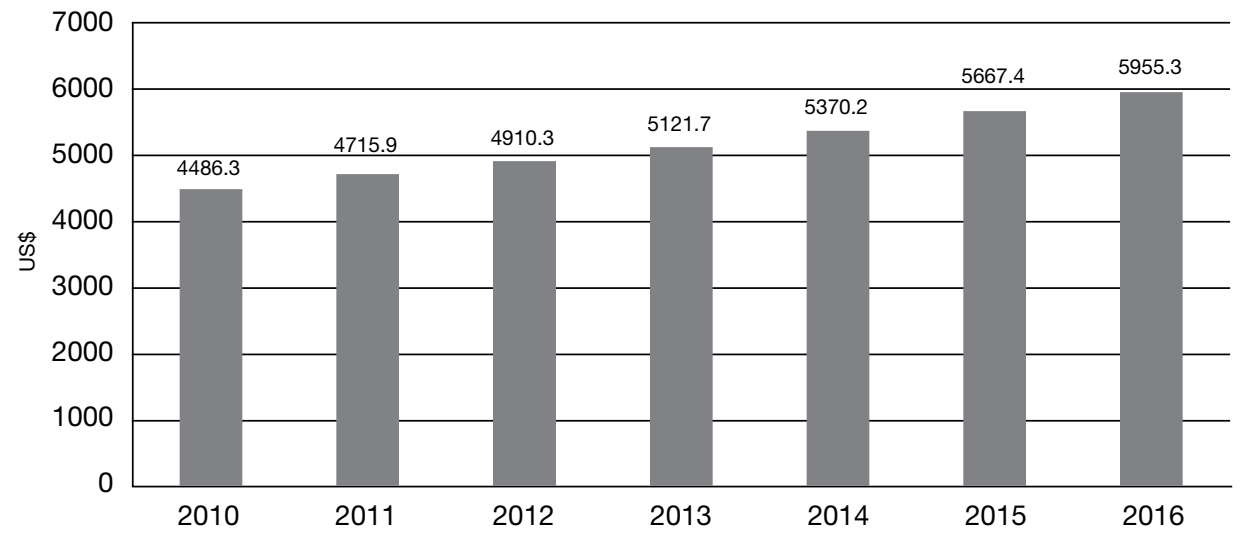

Source: FAO (2018).

From 2010 to 2016, the annual GDP per capita of Viet Nam increased by $\$ 1,500$ from $\$ 4.486$ in 2010 to nearly $\$ 6,000$ in 2016 . This implies that the livelihoods of the country's inhabitants have improved in recent years (figure 2). 


\section{Tea production}

\section{Table 2. Harvested area of tea in Viet Nam (thousand hectares)}

\begin{tabular}{lrrrrc}
\hline \multicolumn{1}{c}{ Country and regions } & $\mathbf{2 0 1 1}$ & $\mathbf{2 0 1 2}$ & $\mathbf{2 0 1 3}$ & $\mathbf{2 0 1 4}$ & $\begin{array}{c}\text { Annual } \\
\text { growth } \\
\text { rate (\%) }\end{array}$ \\
\hline Whole country & 114.3 & 114.5 & 114.8 & 115.4 & 0.32 \\
$\begin{array}{l}\text { Red River Delta } \\
\begin{array}{l}\text { Northern midlands and } \\
\text { mountain area }\end{array}\end{array}$ & 7.5 & 4.6 & 4.4 & 4.6 & 0.34 \\
$\begin{array}{l}\text { North Central and Central } \\
\text { coastal area }\end{array}$ & 6.8 & 80.0 & 81.8 & 82.9 & 1.48 \\
\begin{tabular}{l} 
Central Highlands \\
\hline
\end{tabular} & 23.7 & 23.0 & 21.5 & 20.8 & -4.21 \\
\hline
\end{tabular}

Source: General Statistics Office of Vietnam (2015); author's calculation.

Harvested areas of tea in the country in general and in regions varied slightly over the period 2011-2014. For instance, the harvested area of tea in the country increased by only 0.32 per cent, while it rose by 1.66 per cent in the North Central and Central coastal area, 1.48 per cent in the Northern midlands and mountain area, 0.34 per cent in the Red River Delta, and declined in the Central Highlands by almost 5 per cent. Because of the large planted area of tea in the Northern midlands and mountain area and Central Highlands, in those regions, the harvested area was greatest in 2014 at 82.9 thousand hectares and 20.8 thousand hectares, respectively. In contrast, in 2014, the harvested areas of tea in the North Central and Central coast area and the Red River Delta were small, 71,000 hectares and 4,600 hectares, respectively (table 2).

Table 3. Tea production in Viet Nam (thousand tons)

\begin{tabular}{|c|c|c|c|c|c|}
\hline Country and regions & 2011 & 2012 & 2013 & 2014 & $\begin{array}{l}\text { Annual } \\
\text { growth } \\
\text { rate (\%) }\end{array}$ \\
\hline Whole country & 879.0 & 909.8 & 936.3 & 962.5 & 3.07 \\
\hline Red River Delta & 30.3 & 30.3 & 30.0 & 31.9 & 1.72 \\
\hline $\begin{array}{l}\text { Northern midlands and } \\
\text { mountain area }\end{array}$ & 576.1 & 595.3 & 617.5 & 637.8 & 3.45 \\
\hline $\begin{array}{l}\text { North Central and Central } \\
\text { coastal area }\end{array}$ & 64.0 & 68.3 & 70.6 & 70.8 & 3.43 \\
\hline Central Highlands & 208.6 & 215.9 & 218.2 & 222.0 & 2.10 \\
\hline
\end{tabular}

Source: General Statistics Office of Vietnam (2015); author's calculation. 
Tea production in the country as whole and regionally increased gradually over the period 2011-2014. For example, during that period. tea production in Viet Nam increased by more than 3 per cent annually, with the largest gain recorded in the Northern midlands and mountain area, 3.45 per cent annually, following by 3.43 per cent in the North Central and Central coast area, 2.1 per cent in the Central Highlands, and 1.72 in the Red River Delta. By 2014, the Northern midlands and mountain area had become the dominant region in terms of tea production, with production of 637,800 tons followed by the Central Highlands (222,000 tons), the North Central and Central coast area (70,800 tons) and the Red River Delta (31,900 tons) (table 3).

\section{Table 4. Yield of fresh tea in Viet Nam $(100 \mathrm{~kg} / \mathrm{hectare})$}

\begin{tabular}{lccccc}
\hline \multicolumn{1}{c}{ Country and regions } & $\mathbf{2 0 1 1}$ & $\mathbf{2 0 1 2}$ & $\mathbf{2 0 1 3}$ & $\mathbf{2 0 1 4}$ & $\begin{array}{c}\text { Annual } \\
\text { growth } \\
\text { rate (\%) }\end{array}$ \\
\hline Whole country & 76.9 & 79.5 & 81.6 & 83.4 & 2.74 \\
$\begin{array}{l}\text { Red River Delta } \\
\begin{array}{l}\text { Northern midlands and } \\
\text { mountain area }\end{array}\end{array}$ & 66.7 & 65.9 & 68.2 & 69.3 & 1.30 \\
$\begin{array}{l}\text { North Central and Central } \\
\text { coastal area }\end{array}$ & 94.7 & 74.4 & 75.5 & 76.9 & 1.94 \\
Central Highlands & 88.1 & 99.0 & 99.4 & 99.7 & 1.74 \\
\hline
\end{tabular}

Source: General Statistics Office of Vietnam (2015); author's calculation.

Tea yield varied only slightly during the period 2011-2014. For example, average annual growth of tea yield in the country as a whole increased by 2.74 per cent, while in the Central Highlands, which became the leading region in terms of average growth, the rate was 6.58 per cent and in the other regions, it was below 2 per cent. By 2014 , the tea yield of the country as a whole was $83,400 \mathrm{~kg} / \mathrm{hectare}$. By region, it was $106,700 \mathrm{~kg} /$ hectare in the Central Highlands, $99,700 \mathrm{~kg} / \mathrm{hectare}$ in the North Central and Central coast area, 76,900 kg/hectare in the Northern midlands and $69,300 \mathrm{~kg} / \mathrm{hectare}$ in the Red River Delta $(69,300 \mathrm{~kg} /$ hectare). The Central Highlands have become the leading region in terms of tea yield because of its soil, climate and the application of advanced techniques (new varieties, fertilizer and chemical applications, irrigation, and harvested methods) to produce tea (table 4).

The limited volatility associated with tea yield in the country and regions during the period 2011-2014 can be attributed to the limited expansion in the harvested area of tea. Accordingly, in terms of tea cultivation, tea yield can be increased by planting new varieties, adapting fertilizer and pesticide applications and using harvested techniques instead of implementing intensification. 


\section{METHODOLOGY}

\section{Sample}

The research for this study was conducted in Phu Tho province. In that province, eleven districts are planting tea. However, as farmers in some of the districts were not interviewed because of the limitations in time and human and financial resources, it was necessary to carry out sampling in this study. As a result, a fourstage sample was designed to collect primary data. First, at the provincial level, five districts, including Tan Son, Thanh Son, Thanh Ba, Yen Lap, and Ha Hoa in Phu Tho province, were chosen because they satisfy the following criteria: (1) farmers plant tea and harvested areas in those districts comprise the five largest areas for growing tea in Phu Tho province; (2) existence of coordinated models between producers and enterprises in tea production; (3) permission granted from provincial and district authorities to carry out this study; and (4) access to the list of contracted farmers from enterprises that operate in those districts. Second, nine communes were selected from five districts, including Thai Ninh, Dong Linh, and Van Linh communes in Thanh Ba district, Yen Ky commune in Ha Hoa district, Tan Phu, Van Luong, and Minh Dai communes in Tan Son district, Van Mieu commune in Thanh Son district, and Ngoc Lap commune in Yen Lap district. The next step taken was the selection of 18 villages from the nine communes (two villages in a commune) for conducting interviews. To do this, discussions were held with the chairmen of the communes and leaders of the villages to confirm that there were at least two types of tea households, such as either tenants and independent farmers or contracted and independent farmers in a chosen village. Finally, 358 households were chosen randomly to interview from the 18 villages.

In addition, it must be noted, that the researchers are not sure about the exact number of tea households in Phu Tho province or how many of them are engaged in contracted farming because of limited data released by statistical offices. Based on the objective to obtain a significant level at 5 per cent the sample size for the household survey is as follows:

$n=\left[Z^{2} P(1-P)\right] / d^{2}$ (Daniel and Cross, 2013).

In which, $\mathrm{n}$ is the sample size; $\mathrm{Z}$ is $\mathrm{Z}$-Score (with a 95 per cent confident interval, $Z$ is equal 1.96); $P$ is expected prevalence or proportion $(P=0.5$ is large enough for the sample); and $d$ is precision ( $d=5$ per cent can be accepted for this research). 
Based on the above formula, the calculated sample size is 385 farm households $(n=385)$. However, because of some of the households were in remote areas, and could not be interviewed, data were attained and entered and analysed for this research in only 358 households.

Table 5. The sample of households interviewed in Phu Tho province

\begin{tabular}{lcccccc}
\hline \multicolumn{1}{c}{ Items } & $\begin{array}{c}\text { Thanh Ba } \\
\text { district }\end{array}$ & $\begin{array}{c}\text { Ha Hoa } \\
\text { district }\end{array}$ & $\begin{array}{c}\text { Tan Son } \\
\text { district }\end{array}$ & $\begin{array}{c}\text { Thanh Son } \\
\text { district }\end{array}$ & $\begin{array}{c}\text { Yen Lap } \\
\text { district }\end{array}$ & Total \\
\hline $\begin{array}{l}\text { Contracted } \\
\text { farmers }\end{array}$ & 1 & 0 & 86 & 36 & 41 & 164 \\
$\begin{array}{l}\text { Independent } \\
\text { farmers }\end{array}$ & 87 & 5 & 97 & 5 & 0 & 194 \\
\begin{tabular}{l} 
Total \\
\hline
\end{tabular} & 88 & 5 & 183 & 41 & 41 & 358 \\
\hline
\end{tabular}

Source: Author's calculation.

Households that had cultivated or are cultivating tea in the districts of Phu Tho province were selected for the interview. Of the 358 households interviewed, 164 were contracted farmers and 194 were independent farmers. Contracted farmers, on average, had signed contracts for a duration of one to five years. Independent farmers had no contracts with firms and often grow tea on their own land and sell their production in the open markets. The list of independent households was provided by commune authorities and leaders of villages while the list of contracted producers was provided by managers of enterprises (table 5).

\section{Surveys}

The purpose of the surveys was to gather detailed information on the effects of contract farming on productivity and income of farm households in tea production in Phu Tho province. Interviewers included a Higher Degree Research student and six undergraduate students who were studying business administration or accounting at the Viet Nam National University of Agriculture. The questionnaires comprised 62 questions. Prior to conducting the interviews, the questionnaires were translated into Vietnamese. All of the interviewers were trained by the Higher Degree Research student to obtain a full understanding of the survey.

The face-to-face method of survey was selected to minimize the non-response rate. Specifically, the interviewers asked the respondents for information based on questionnaires and the answers were recorded on answer sheets. Each interview took, on average, one hour and was conducted in the respondents' homes, fields or village offices. Respondents had expressed their willingness to participate in the interview by signing a consent form. 


\section{Data analysis}

The primary data were managed through Microsoft Excel software and then analysed using Stata MP 14.2 software.

\section{Stochastic frontier model}

In economics, productivity and efficiency terms are used interchangeably (Coelli and others, 2005). This is also the case for this study. Productivity can be measured by the ratio of the amount of output produced to the amount of resource used (Henningsen and others, 2015). Tea productivity is computed by the volume of leaf tea harvested by households for a year.

In this research, the stochastic frontier model was chosen because of the following: it presents a disturbance term denoting statistical noise, measurement error and exogenous effects out of the control of production units, and it allows performing statistical tests of hypotheses regarding the production structure and the degree of inefficiency (Hassan and Ahmad, 2005). To estimate the impact of contract farming on tea productivity, three stages were carried out: (1) employing stochastic frontier models to estimate factors affecting tea productivity; (2) demonstrating the efficient levels of tea production; and (3) employing a propensity score matching to investigate the effects of contract farming on tea productivity. In this research, the propensity scoring matching was used to match individuals in the contracted farmer group to members in the independent farmer group with a set of observed characteristics in the form of a propensity score.

To estimate influences of determinants on tea productivity, the framework carried out by Bravo-Ureta and others (2012) was applied, which entailed designing two stochastic frontier models, one for contracted farmers and one for independent farmers. However, the issue of unobserved differences among contracted farmers and independent farmers needed to be dealt with. The stochastic frontier model proposed by Greene (2010) was used to solve this problem. 
The specification of this model can be represented as follows:

$$
\begin{aligned}
& Y i=\beta c^{\prime} X_{i}+\varepsilon_{i} \text { for } D_{i}=1 \\
& Y_{i}=\beta n^{\prime} X_{i}+\varepsilon_{i} \text { for } D_{i}=0 \\
& D_{i}=1\left[\alpha^{\prime} Z_{i}+W_{i}>0\right] \\
& \varepsilon_{i}=V_{i}-U_{i} \\
& U_{i} \sim N^{+}\left(0, \delta c_{u}\right) \text { for } D_{i}=1 \\
& U_{i} \sim N^{+}\left(0, \delta c_{u}\right) \text { for } D_{i}=0 \\
& W_{i}, V_{i} \sim N^{2}[0,0],\left(1, \lambda c, \delta c_{v}, \delta c 2_{v}\right) \text { for } D_{i}=1 \\
& W_{i}, V_{i} \sim N^{2}[0,0],\left(1, \lambda n, \delta n_{v}, \delta n 2_{v}\right) \text { for } D_{i}=0
\end{aligned}
$$

Where: $Y_{i}$ represents the logarithmic output quantity of tea of producer $i=1, \ldots$, $\mathrm{N} ; \mathrm{X}_{\mathrm{i}}$ denotes a vector of logarithmic input quantity (planted area, family labourers, capital, fertilizers, chemical, etc.); $D_{i}$ is a dummy variable ( 1 for contracted farmers and 0 for independent farmers); $Z_{i}$ is a vector of covariates in the sample selection equation; $\varepsilon_{i}$ denotes the error term of the stochastic frontier model; $V_{i}$ represents noise (managerial ability, etc.); $U_{i}$ is inefficiency; $W_{i}$ denotes the error term of the selection equation; $\alpha, \beta^{c}$ and $\beta^{n}$ are parameters to be estimated.

Assumptions for this model: $U_{i}$ follows a half-normal distribution with dispersion parameter $\delta^{c}$ and $\delta^{n}{ }_{u} ; W_{i}$ and $V_{i}$ follow a bivariate normal distribution with variances 1 and $\delta^{\mathrm{c} 2}{ }_{v}$ and $\delta^{\mathrm{n} 2}{ }_{\mathrm{v}} ; \lambda^{\mathrm{c}}$ is correlation coefficient of contracted farmers; $\lambda^{\mathrm{n}}$ is correlation coefficient of independent farmers; and non-zero values of $\lambda^{c}$ and $\lambda^{n}$ expresses selfselection.

Based on a two-stage estimation procedure proposed by Greene (2010), technical efficiency in tea production of contracted farmers and independent farmers can be estimated $\left[\mathrm{TE}_{\mathrm{i}}=\mathrm{E}\left(\mathrm{e}^{-\mathrm{Ui}}\right)\right]$. 
Table 6. Description of covariates in the stochastic frontier model

\begin{tabular}{llll}
\hline Variable definitions & Labels & Unit & $\begin{array}{c}\text { Expected } \\
\text { signs }\end{array}$ \\
\hline
\end{tabular}

1. Stochastic model

Dependent variable: Productivity (total volume of leaf tea harvested by a household in a year)

Y $\quad$ kilogram $(\mathrm{kg})$

\section{Independent variables:}

Family labourers

Land size for tea plantation

Capital for tea production

Quantity of mixed fertilizer (NPK)

Pesticide costs for tea

Density: the average number of tea trees grown in an area

$\begin{array}{lcc}\mathrm{X}_{1} & \text { person } & +/- \\ \mathrm{X}_{2} & \text { sao } & + \\ \mathrm{X}_{3} & \mathrm{~d} 1,000 & + \\ \mathrm{X}_{4} & \mathrm{~kg} / \mathrm{sao} / \mathrm{year} & + \\ \mathrm{X}_{5} & \mathrm{~d} 1,000 / \mathrm{sao} & +/- \\ \mathrm{X}_{6} & \text { tree/sao } & +/-\end{array}$

\section{Inefficiency model}

Dependent variable: the level of inefficiency

$U_{i}$

\section{Independent variables:}

Age of household heads

Gender ( $1=$ Male and $0=$ Female)

Education level of household heads

Household categories (1=Poor households and $0=$ Otherwise)

Harvested times: number of harvested times in a year

Harvested methods ( $1=$ Machine and $0=$ Otherwise $)$

$\begin{array}{llc}X_{7} & \text { years } & +/- \\ D_{1} & & +/- \\ X_{8} & \text { years } & - \\ D^{2} & & +/-\end{array}$

$\mathrm{X}^{9} \quad$ times $\quad+/-$

Note: Sao is an area unit ( 1 sao is equal to 360 square meters).

\section{Propensity score matching}

Regression analysis may be used to investigate the influence of contract farming on tea productivity, sales and income of farmers. The specification of the model can be represented as follows (Heckman, 1979):

$$
Y=\beta X_{i}+\alpha A_{i}+\varepsilon_{i}
$$


Where: $Y$ represents tea productivity of households; $X_{i}$ denotes explanatory variables; $\beta$ and $\alpha$ are coefficients to be estimated; $A_{i}$ is dummy variable ( 1 for contracted farmers and 0 for independent ones); and $\varepsilon_{i}$ is the error term.

However, participation of farmers in the contract is non-random as contract participation depends on either the selection of contractors or the situation of farm households. Hence, the decision of farmers on whether to participate in a contract is unobservable. As a result, the correlation between $A_{i}$ and $\varepsilon_{i}$ violates one of the key assumptions of ordinary least square (OLS), which generates a bias estimation. Different methods have been proposed to deal with that issue. Some scholars have employed the Heckman two-step method, while others have used an instrumental variable (IV) to fix selection bias (Meshesha, 2011; Bellemare, 2012; Key, 2013; Kumar and others, 2016). The Heckman two-step model depends heavily on the assumption of normal distribution in error terms. IV is strict because it is very difficult to specify appropriate instruments in the estimation (Wainaina and others, 2012). To overcome those challenges, propensity score matching is employed in this study to assess the impacts of contract farming on tea productivity of farmers.

Propensity scoring matching is used to match individuals in the comparison group to members in the treatment group with a set of observed characteristics in the form of a propensity score. The propensity is used to predict probability of participation in an intervention (Baker, 2000). Propensity score matching is a non-experimental method developed to estimate the average effect of social programmes (Rosenbaum and Rubin, 1983; Heckman and others, 1998). In propensity scoring matching, average outcomes of participants and non-participants are compared under the condition of the propensity score value. Consequently, the match is good if the treatment group is matched to the control group with a closer propensity score (Baker, 2000).

Propensity scoring matching was applied in this research because it can correct the potential selection biasedness, which tends to increase because of systematic differences between the participants and non-participants (Ali and others, 2013). For example, contracted farmers can obtain greater tea productivity compared to other types of tea farmers because of technical assistance offered by the enterprises contracting the tea production. Moreover, contracted farmers may sell a larger volume of leaf tea compared to independent ones because businesses often agree to purchase the leaf tea after harvesting based on terms of the contract.

The procedures for propensity scoring matching are comprised of six steps. In the first step, the determinants affecting contract participation are estimated by running a binary logistic model. The objective of that assignment is to estimate propensity scores of covariates in the sample of both contracted and independent farmers. The second step is the demonstration of the distribution of households with respect to 
the estimated propensity scores of both contracted and independent farmers. The next step is selection of a matching algorithm. In that step, a matching algorithm is used to balance comparison groups by matching treatment group individuals with suitable controls. There are various matching algorithms, such as the nearestneighbor matching (NNM), caliper matching, radius matching, Kernel matching (KM), and Mahalanobis metric matching (Ali and others, 2013). The fourth step is assessment on the match quality. That step may be implemented by the psmatch2 routine proposed by Leuven and Sianesi (2003). Outputs of the step include the estimated treatment effect with its standard errors and confidence interval, in addition to a number of diagnostics used to examine the match quality. In addition, covariate distributions before and after matching are compared. The matching is successful if the distribution of all covariates in treatment and control groups is balanced (Gemici and others, 2012). The fifth step is estimation of average treatment effects on the treated (ATT). The objective of that step is to assess impacts of contract participation on tea productivity, revenue, and income of farmers. The final step is implementation of sensitivity analysis. The purpose of it is to examine the possibility of hidden bias from unobserved covariates.

To evaluate the impact of contract participation on tea productivity, the observable characteristics need to be homogeneous between contracted farmers (the treatment group) and independent farmers (the control group). The expected treatment effect of contract participation or ATT can be measured by the difference between the actual tea productivity and tea productivity if farmers did not participate in the contract. ATT can be specified as follows:

$$
A T T=E\left(T_{1 i}-T_{0 i} / Z_{i}=1\right)
$$

Where ATT denotes average treatment effect on the treated for tea productivity; $T_{1 i}$ represents tea productivity when the farmer participates in the contract; $T_{0 i}$ represents tea productivity when the farmer did not participate in the contract; and $Z_{i}$ denotes the contract participation ( 1 for contract participation and 0 for otherwise).

Covariates in the treatment effect model for tea productivity are presented in table 7 . 
Table 7. Description of covariates in the treatment effect model for tea productivity

\begin{tabular}{|c|c|c|c|}
\hline Variable definitions & Labels & Unit & $\begin{array}{l}\text { Expected } \\
\text { signs }\end{array}$ \\
\hline $\begin{array}{l}\text { 1. Treatment variable: contract participation }(Z=1 \text { for } \\
\text { contract participation and } Z=0 \text { for otherwise) }\end{array}$ & Z & & \\
\hline \multicolumn{4}{|l|}{ 2. Covariates } \\
\hline Age of household heads & $\mathrm{X}_{1}$ & years & $+/-$ \\
\hline Gender ( $1=$ Male and $0=$ Female) & $D_{1}$ & & $+/-$ \\
\hline $\begin{array}{l}\text { Household categories ( } 1=\text { Poor households and } \\
0=\text { Otherwise) }\end{array}$ & $\mathrm{D}_{2}$ & & $+/-$ \\
\hline Family labourers & $x_{2}$ & person & $+/-$ \\
\hline Land size for tea plantation & $\mathrm{X}_{3}$ & sao & + \\
\hline Tea age & $\mathrm{X}_{4}$ & years & + \\
\hline Density: number of tea trees grown in an area & $X_{5}$ & tree/sao & + \\
\hline Harvested times & $\mathrm{X}_{6}$ & times & $+/-$ \\
\hline Harvested methods ( $1=$ Machine and $0=$ Otherwise) & $\mathrm{D}_{3}$ & & $+/-$ \\
\hline $\begin{array}{l}\text { 3. Outcome variable: tea productivity (total volume of } \\
\text { leaf tea harvested by a household) }\end{array}$ & $\mathrm{T}$ & kg/year & \\
\hline
\end{tabular}

\section{RESULTS}

\section{Characteristics of tea households in Phu Tho province}

The average age of the heads of tea households is 48.7 and age of contracted and independent farmers is about the same. The average number of school years implies that most household heads have just graduated from secondary school. The average number of members and labourers in a family are 5 and 2.7, respectively; the families of contracted farmers have slightly more members and labourers than independent ones. On average, independent contractors have more land and allocate more land to grow tea than contracted households by more than eight sao and six sao, respectively. The asset value of tea households is about 53 million Viet Nam dong (d) $(\$ 2,311)$. Capital for tea production of contracted farmers is higher than that of their counterparts by about $₫ 3$ million. Similarly, tree density of contracted households is higher than that of independent ones by nearly 100 trees per sao. However, the experience in tea production and the age of independent farmers are higher than those of contracted households. Tea is harvested more than five times a year by independent farmers and contracted farmers. The price of tea produced by contracted households is higher than the price of tea produced by independent farmers by about $\mathbb{\AA} 1,000$ per kilogram (table 8 ). 


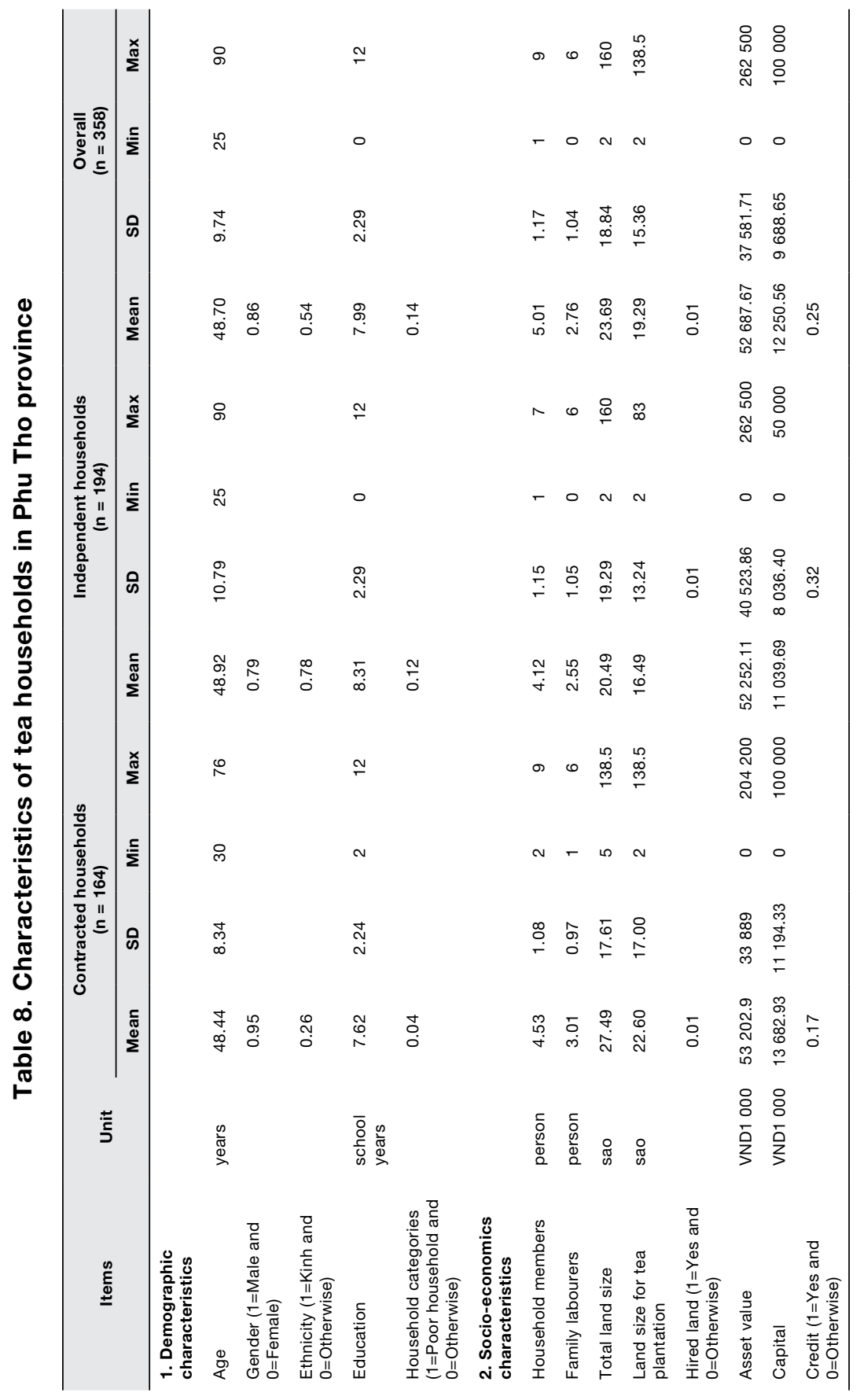




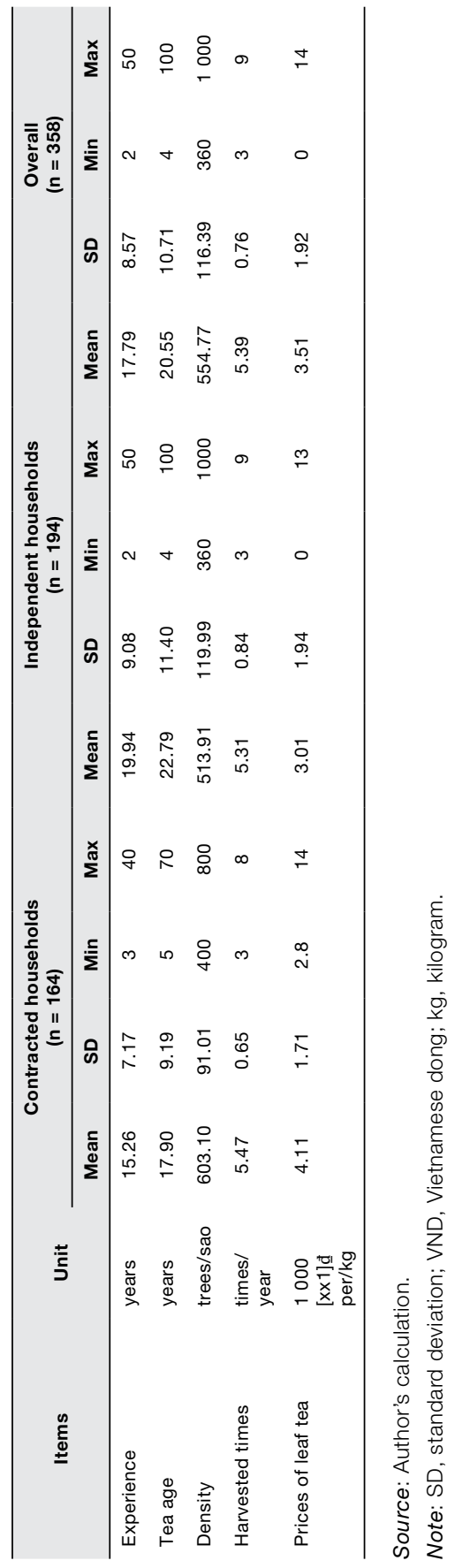




\section{Estimation of tea productivity and technical efficiency of tea production}

Tea productivity and technical efficiency of contracted farmers

Maximum likelihood estimates of the stochastic frontier model and the inefficiency model for tea production of contracted farmers are presented in table 9.

Table 9. Maximum estimates of the stochastic frontier model and inefficiency model for contracted farmers

\begin{tabular}{|c|c|c|c|c|}
\hline Variables & Coefficient & Standard error & $\mathbf{Z}$ & $P>[z]$ \\
\hline \multicolumn{5}{|l|}{ Stochastic model } \\
\hline LnLabourers & 0.063 & 0.104 & 0.60 & 0.545 \\
\hline LnLand size for tea & $0.809^{\star \star \star}$ & 0.051 & 15.78 & 0.000 \\
\hline Ln2Capital & 0.007 & 0.027 & 0.26 & 0.798 \\
\hline LnNPK & 0.024 & 0.046 & 0.52 & 0.605 \\
\hline LnPesticide & $0.062^{*}$ & 0.037 & 1.66 & 0.097 \\
\hline LnDensity & $-0.699^{\star \star \star}$ & 0.241 & -2.90 & 0.004 \\
\hline Constant & $11.065^{\star \star \star}$ & 1.429 & 7.74 & 0.000 \\
\hline \multicolumn{5}{|l|}{ Inefficiency model } \\
\hline Age & $0.028^{*}$ & 0.016 & 1.74 & 0.083 \\
\hline Gender & $1.756^{\star \star \star}$ & 0.671 & 2.62 & 0.009 \\
\hline Education & $-0.195^{\star \star \star}$ & 0.065 & -2.99 & 0.003 \\
\hline Household categories & 0.357 & 0.606 & 0.59 & 0.556 \\
\hline Harvested times & -0.110 & 0.171 & -0.64 & 0.521 \\
\hline Harvested methods & -0.081 & 0.240 & -0.34 & 0.735 \\
\hline Constant & -1.537 & 1.262 & -1.22 & 0.223 \\
\hline Noise variation $\left(\delta_{\mathrm{v}}\right)$ & 0.150 & & & \\
\hline Inefficiency variation $\left(\delta_{u}\right)$ & 0.830 & & & \\
\hline $\begin{array}{l}\text { Total error variance }\left(\delta^{2}=\delta_{v}{ }^{2}\right. \\
\left.+\delta_{u}{ }^{2}\right)\end{array}$ & 0.712 & & & \\
\hline Signal-to-noise ratio $\left(\lambda=\delta_{\mathrm{u}} / \delta_{\mathrm{v}}\right)$ & 5.499 & & & \\
\hline Observations & 164 & & & \\
\hline LogLikelihood & -101.35 & & & \\
\hline Prob > chi2 & 0.00 & & & \\
\hline \multicolumn{5}{|c|}{ LR test of $\delta_{u}=0$ chibar $2(01)=33.93$ Prob $>=$ chibar $2=0.00$} \\
\hline
\end{tabular}

Source: Author's calculation.

Note: ${ }^{* \star}$ Significance at the 0.01 ; ${ }^{\star}$ significance at the 0.1 . 
Values of loglikelihood and prob>chi2 account for -112.14 and 0.00 , respectively; they imply the fitness of the half-normal model. Noise variation and inefficiency variation are equal to 0.15 and 0.83 , respectively. Value of lambda is greater than 1 $(\lambda=5.499)$; this suggests that the most of the variation in tea productivity is outweighed by inefficiency effects (table 9 ).

To test technical inefficiency in the model, hypotheses are designed as follows:

Null hypothesis $(\mathrm{Ho})$ : There is no technical inefficiency in the model $\left(\delta_{\mathrm{u}}=0\right)$

Alternative hypothesis $(\mathrm{Ha})$ : There is technical inefficiency in the model $\left(\delta_{u}>0\right)$

Null hypothesis is rejected if the $p$-value is either less than or equal to the predetermined value $(0.05)$ while null hypothesis is accepted if the $p$-value is greater than the predetermined value $(0.05)$. In that case, the $p$-value is less than the predetermined value $(0.00<0.05)$. As a result, it can be concluded that technical inefficiency exists in the model (table 9).

In the stochastic model, land size, pesticide cost, and density are statistically significant, while the other variables (labourers, capital and quantity of mixed fertilizer) are not significant. Land size and pesticide cost present a positive relationship with tea productivity, which implies that an increase in land size and pesticide cost leads to a rise of tea productivity. Land is a key input for tea production; consequently, tea productivity may be enhanced if farm households have more land area. In fact, according to estimates for this study, expenditure for tea production of farmers in Phu Tho province varies from $₫ 700,000$ loglikelihood to đ1 million per sao a year (\$31-44/sao/year). Of total cost of tea production, labour cost accounts for 47.2 per cent, input cost (fertilizers, pesticides and materials) accounts for 52.4 per cent, and other cost account for 0.4 per cent. Accordingly, the majority of the total cost is dominated by costs for fertilizers, pesticides, and materials. In recent years, extensive use of pesticides and chemicals has become an issue for the tea sector in Viet Nam as tea producers can more easily purchase them in the open market. This is because, those inputs are more readily available, have come down in price and market surveillance agencies are not in a position to effectively control the distribution of them. Specifically, purchasing inputs in open markets is convenient because those markets are near residential communities or within villages, and prices can be negotiated between buyers and sellers. Ineffective control of the inputs by market surveillance agencies has occurred because of lack of professional staff and unclear responsibilities among surveillance, policemen, health, and agricultural agencies. By contrast, density adversely affects tea productivity, which suggests that if farmers grow more tea trees in an area, tea productivity tends to decline. The average number of tea trees planted by contracted farmers is 603 trees per sao. 
According to experts, the most suitable density level for tea trees in Phu Tho province varies from 470 trees to 500 trees a sao. Consequently, a rise in density of tea trees leads to lower productivity (table 9).

For the inefficiency model, age, gender and education are statistically significant, while the other variables (household categories, harvested times and harvested methods) are not significant. The positive coefficient of age implies that older producers obtain higher technical inefficiency, which indicates that the technical efficiency of tea production depends on technological advances rather than the experience of the producers. Specifically, if the age of the producers increases by a year, then the technical inefficiency of tea production rises by 2.8 per cent, with other factors staying the same. The coefficient of gender is positive, which implies that technical efficiency of female-head households is higher than that of male-head households. This result may be explained by carefulness and sensitivity of females with regard to tea production. In contrast, education presents a negative relationship with technical inefficiency of tea production. This suggests that households with higher education levels gain higher technical efficiency compared to their counterparts. This signifies the importance of knowledge in employing and adopting technological advances in tea production. Most contracted farmers have only graduated from secondary school. So, boosting their education levels is necessary to enhance technical efficiency of tea farmers in Phu Tho province (table 9).

Levels of technical efficiency of tea production of contracted farmers are presented in table 10. The average technical efficiency level is 0.599 , which implies that the technical inefficiency of tea production of contracted households is 40.1 per cent. The maximum and minimum technical efficiency rates are 94.7 per cent and 10.9 per cent. The largest number of households, 55, or 33.5 per cent of the sample households, had low technical efficiency (below 50 per cent) with regard to tea production. The next largest number of households, 20.1 per cent of them, have a technical efficiency of 80-90 per cent, followed of 17 per cent of them having technical efficiency of 70-80 per cent, 14.6 per cent of them having technical efficiency of 60-70 per cent level, 10.3 per cent having technical efficiency of 50-60 per cent level, and seven households with technical efficiency that exceeds 90 per cent (table 10). 


\section{Table 10. Technical efficiency of tea production of contracted farmers}

\begin{tabular}{lcc}
\hline Levels of technical efficiency & Frequency & Per cent \\
\hline$<50 \%$ & 55 & 33.54 \\
$50-60 \%$ & 17 & 10.37 \\
$60-70 \%$ & 24 & 14.63 \\
$70-80 \%$ & 28 & 17.07 \\
$80-90 \%$ & 33 & 20.12 \\
$>90 \%$ & 7 & 4.27 \\
TOTAL & 164 & 100.00 \\
\hline Average TE & 0.599 & \\
Min TE & 0.109 & \\
Max TE & 0.947 & \\
\hline
\end{tabular}

Source: Author's calculation.

Tea productivity and technical efficiency of independent farmers

Maximum likelihood estimates of the stochastic frontier model and the inefficiency model for tea production of independent farmers are presented in table 11.

Loglikelihood and p-value account for -179.94 and 0.00 , respectively, implying the fitness of the half-normal model. Noise variation and inefficiency variation account for 0.337 and 0.92 , respectively. Value of lambda is greater than $1(\lambda=2.731)$, which indicates that the majority of the variation in tea productivity is dominated by inefficiency effects (table 11).

To test technical inefficiency in the model, the design of the hypotheses is as follows:

Null hypothesis $(\mathrm{Ho})$ : There is no technical inefficiency in the model $(\delta \mathrm{u}=0)$

Alternative hypothesis $(\mathrm{Ha})$ : There is technical inefficiency in the model $(\delta \mathrm{u}>0)$

Null hypothesis will be rejected if the $p$-value is either less than or equal to predetermined value $(0.05)$ and by contrast, null hypothesis is accepted if the $p$-value is greater than the predetermined value (0.05). In this case, $p$-value is less than the predetermined value $(0.00<0.05)$. Accordingly, it can be concluded that technical inefficiency exists in the model (table 11). 
In the stochastic model, land size, capital, and density are statistically significant, while the rest variables (laborers, NPK, and pesticide) are not significant. Similar to contracted households, land is a key input for tea production. Consequently, tea productivity may be increased if independent farmers gain land area. Capital also positively influences tea productivity, which implies that an increase in capital leads to greater tea productivity. The average amount of capital for tea production owned by independent households is đ 11 million. So, the households need to borrow more capital from credit organizations. Density has a negative relationship with tea productivity, which implies that if producers grow more tea trees in an area, then tea productivity tends to decrease. The average number of tea trees planted by independent farmers is 513 trees per sao, which is slightly higher than the density recommended by experts (470-500 trees/sao). Accordingly, an increase in tea density results in lower productivity (table 11). 
Table 11. Maximum likelihood estimates of the stochastic frontier model and inefficiency model for independent farmers

\begin{tabular}{|c|c|c|c|c|}
\hline Variables & Coefficient & Standard error & $\mathbf{Z}$ & $P>[z]$ \\
\hline \multicolumn{5}{|l|}{ Stochastic model } \\
\hline LnLabourers & 0.054 & 0.127 & 0.43 & 0.668 \\
\hline LnLand size for tea & $0.715^{\star \star \star}$ & 0.063 & 11.22 & 0.000 \\
\hline Ln2Capital & $0.133^{\star \star \star}$ & 0.031 & 4.26 & 0.000 \\
\hline LnNPK & 0.047 & 0.044 & 1.06 & 0.291 \\
\hline LnPesticide & 0.003 & 0.036 & 0.10 & 0.920 \\
\hline LnDensity & $-0.388^{*}$ & 0.206 & -1.88 & 0.061 \\
\hline Constant & $8.316^{\star \star \star}$ & 1.280 & 6.49 & 0.000 \\
\hline \multicolumn{5}{|l|}{ Inefficiency model } \\
\hline Age & $0.025^{\star}$ & 0.013 & 1.94 & 0.052 \\
\hline Gender & 0.478 & 0.312 & 1.53 & 0.125 \\
\hline Education & -0.029 & 0.055 & -0.54 & 0.591 \\
\hline Household categories & 0.278 & 0.283 & 0.98 & 0.325 \\
\hline Harvested times & $-0.260^{\star}$ & 0.149 & -1.75 & 0.081 \\
\hline Harvested methods & -0.224 & 0.734 & -0.31 & 0.759 \\
\hline Constant & -0.080 & 1.247 & -0.06 & 0.949 \\
\hline Noise variation $\left(\delta_{v}\right)$ & 0.337 & & & \\
\hline Inefficiency variation $\left(\delta_{u}\right)$ & 0.920 & & & \\
\hline $\begin{array}{l}\text { Total error variance }\left(\delta^{2}=\delta_{v}{ }^{2}\right. \\
\left.+\delta_{u}{ }^{2}\right)\end{array}$ & 0.961 & & & \\
\hline Signal-to-noise ratio $\left(\lambda=\delta_{u} / \delta_{v}\right)$ & 2.731 & & & \\
\hline Observations & 194 & & & \\
\hline LogLikelihood & -179.94 & & & \\
\hline Prob > chi2 & 0.00 & & & \\
\hline \multicolumn{5}{|c|}{ LR test of $\delta_{u}=0$ chibar2 $(01)=33.93$ Prob $>=$ chibar2 $=0.00$} \\
\hline
\end{tabular}

Source: Author's calculation.

Note: ${ }^{\star \star \star}$ Significance at the 0.01 ; ${ }^{\star}$ significance at the 0.1 .

For the inefficiency model, age and harvested times are statistically significant, while the other variables (gender, education, household categories, and harvested methods) are not significant. The positive coefficient of age suggests that older producers obtain a lower technical efficiency, which implies that technical efficiency of tea production depends on technological advances and not on the experience of 
producers. Specifically, if the age of producers increases by a year, then the technical inefficiency of tea production rises by 2.5 per cent, with all other factors remaining the same. In contrast, harvested time negatively affects technical inefficiency, which indicates that if harvested time increases, then technical efficiency also goes up. The average number of harvested times carried out by independent farmers is 5.3 . Experts recommend that growers harvest leaf tea nine or ten times a year and that the gap between two harvests should be from seven to ten days. Technical efficiency of tea production can be increased if farmers harvest leaf tea more frequently (table $11)$.

The levels of technical efficiency of tea production of independent farmers are presented in table 12 .

Table 12. Technical efficiency of tea production of independent farmers

\begin{tabular}{lcc}
\hline Levels of technical efficiency & Frequency & Per cent \\
\hline$<50 \%$ & 74 & 38.14 \\
$50-60 \%$ & 30 & 15.46 \\
$60-70 \%$ & 22 & 11.34 \\
$70-80 \%$ & 49 & 25.26 \\
$80-90 \%$ & 18 & 9.28 \\
$>90 \%$ & 1 & 0.52 \\
TOTAL & 194 & 100.00 \\
\hline Average TE & 0.551 & \\
Min TE & 0.127 & \\
Max TE & 0.914 & \\
\hline
\end{tabular}

Source: Author's calculation.

Average technical efficiency is equal to 0.551 , which implies that technical inefficiency of tea production of contracted households accounts for 44.9 per cent. The maximum and minimum levels of technical efficiency are 91.4 per cent and 12.7 per cent, respectively. The largest number of households in the sample group, 74 , or 38.1 per cent, have low technical efficiency (below 50 per cent), followed by 25.2 per cent with technical efficiency of 70-80 per cent, 15.4 per cent with technical efficiency of 50-60 per cent level of 11.3 per cent with technical efficiency of 60-70 per cent level, 9.2 per cent with technical efficiency of 80-90 per cent level, and only one household with technical efficiency of more than 90 per cent (table 12). 


\section{Impacts of contract farming on tea productivity}

Estimation of determinants affecting contract participation (propensity scores estimation)

Table 13. Characteristics of contracted and independent farmers

\begin{tabular}{|c|c|c|c|}
\hline Variables & $\begin{array}{c}\text { Contracted } \\
\text { farmers (Mean) }\end{array}$ & $\begin{array}{c}\text { Independent } \\
\text { farmers (Mean) }\end{array}$ & $\begin{array}{c}\text { T-test } \\
\text { (Difference) }\end{array}$ \\
\hline Number of observations & 164 & 194 & \\
\hline Age & 48.44 & 48.92 & 0.48 \\
\hline Gender & 0.95 & 0.79 & $-0.16^{\star \star *}$ \\
\hline Household categories & 0.04 & 0.12 & $0.18^{\star \star \star}$ \\
\hline Family labourers & 3.01 & 2.55 & $-0.45^{\star \star *}$ \\
\hline Land size for tea & 22.60 & 16.49 & $-6.10^{\star \star \star}$ \\
\hline Tea age & 17.90 & 22.79 & $4.88^{\star \star \star}$ \\
\hline Density & 603.10 & 513.91 & $-89.19^{\star \star \star}$ \\
\hline
\end{tabular}

Source: Author's calculation.

Note: ${ }^{* \star *}$ Significance at the 0.01

Seven covariates, consisting of age, gender, household categories, family labors, land size for tea, tea age, and density, are chosen to include the propensity score because these variables present potential impacts on tea productivity. Next, t-test is used to check the difference in means of covariates between contracted and independent farmers. The results show that the difference in means of all variables, except age, is statistically significant at 1 per cent (table 13).

The logistic model is employed to estimate determinants affecting contract participation. 
Table 14. Logistic model of factors determining contract participation

\begin{tabular}{|c|c|c|c|c|c|}
\hline Variables & Coefficient & $\begin{array}{l}\text { Standard } \\
\text { error }\end{array}$ & $\mathbf{z}$ & $P>[z]$ & $\begin{array}{c}\text { Marginal } \\
\text { effect }\end{array}$ \\
\hline \multicolumn{6}{|l|}{$\begin{array}{l}\text { Dependent variable: } \\
\text { contract participation } \\
\text { ( } 1 \text { for contract } \\
\text { participation and } 0 \text { for } \\
\text { otherwise) }\end{array}$} \\
\hline Age & 0.014 & 0.013 & 1.05 & 0.293 & 0.002 \\
\hline Gender & $1.655^{\star \star \star}$ & 0.465 & 3.56 & 0.000 & $0.290^{\star \star \star}$ \\
\hline Household categories & $-1.614^{\star \star \star}$ & 0.453 & -3.56 & 0.000 & $-0.283^{\star \star *}$ \\
\hline Family labourers & $0.245^{*}$ & 0.126 & 1.93 & 0.053 & $0.043^{\star \star}$ \\
\hline Land size for tea & $0.018^{\star \star}$ & 0.008 & 2.13 & 0.033 & $0.003^{\star *}$ \\
\hline Tea age & $-0.039^{\star * *}$ & 0.014 & -2.69 & 0.007 & $-0.007^{\star \star *}$ \\
\hline Density & $0.006^{\star \star \star}$ & 0.001 & 5.17 & 0.000 & $0.001^{\star \star \star}$ \\
\hline Constant & $-6.013^{\star \star \star}$ & 1.173 & -5.12 & 0.000 & \\
\hline Number of observations & 358 & & & & \\
\hline LR chi2(7) & 118.32 & & & & \\
\hline Prob > chi2 & 0.000 & & & & \\
\hline Pseudo R2 & 0.239 & & & & \\
\hline Log likelihood & -187.72 & & & & \\
\hline
\end{tabular}

Source: Author's calculation.

Note: ${ }^{* \star}$ Significance at the 0.01 ; significance at the 0.05 ; significance at the 0.1 .

Value of Pseudo R squared is equal to 0.239 implies that 23.9 per cent of variation in contract participation is explained by independent variables in the model. P-value and log likelihood account for 0.000 and -187.72 , respectively reflect the fitness of the model (table 14).

All independent variables are statistically significant, except age. Gender, family labourers, land size for tea, and density present positive relationships with contract participation, while household categories and tea age negatively influence contract participation. Specifically, the probability that male-headed households will participate in contracted is higher than that of female-headed households by 29 per cent, with all other factors remaining the same. Major decisions are often implemented by the men in farm households in the rural area of Viet Nam. Moreover, male-headed households tend to accept risks rather than female-headed households (table 14).

Family labour and land size are key resources for tea production. Hence, if the labourers and land size of households increase by one person and a sao, then 
probability of contract participation rises by 4.3 per cent and 0.3 per cent, respectively, with all other factors remaining the same. If tea density rises by a tree/sao, then the probability of contract participation increases by 0.1 per cent, with all other factors remaining the same. This implies that households, who grow more tea trees in an area, prefer to participate in the contract rather than their counterparts (table 14).

Probability in contract participation of non-poor households is higher than that of poor households by 28.3 per cent, with all other factors remaining the same. Nonpoor households tend to participate in the contract rather than poor households, as the number of labourers and amount of land and capital of non-poor households are larger than those of their counterparts. If the average age of tea trees increases by a year, then the probability of contract participation decreases by 0.7 per cent. Currently, the average age of tea trees in the survey sample is 21 years. The age of the tea tree has a negative relationship with contract participation because growers believe that old tea trees often produce a lower yield (table 14).

Demonstration of the common support region

The purpose of this step is demonstration of the common support region.

Table 15. Distribution of estimated propensity scores

\begin{tabular}{lccccc}
\hline \multicolumn{1}{c}{ Categories } & Observations & Min & Mean & Max & SD \\
\hline Contracted farmers & 164 & 0.062 & 0.630 & 0.948 & 0.229 \\
Independent farmers & 194 & 0.006 & 0.312 & 0.950 & 0.234 \\
Overall & 358 & 0.005 & 0.450 & 0.950 & 0.280 \\
\hline
\end{tabular}

Source: Author's calculation.

Note: SD denotes standard deviation.

The overall estimated propensity scores are between 0.005 and 0.950 . Among contracted farmers, the propensity scores vary between 0.062 and 0.948 , while the propensity scores range between 0.006 and 0.950 for independent households. This implies that the region of common support would be between 0.062 and 0.950 . Accordingly, outliers that are below and above this range need to be dropped. Out of 358 households, 24 observations (1 from contracted farmers and 23 from independent farmers) are dropped from the analysis as their propensity scores are outside the region of common support. Accordingly, only 334 observations are sufficient to predict the impact of contract participation on tea productivity for this study (table 15). 


\section{Selection of a matching algorithm}

Several criteria, such as number of explanatory variables with insignificant mean difference between the match groups of contracted and independent farmers, pseudo $\mathrm{R}^{2}$, and matched sample size, are tested to choose appropriate matching algorithms. The nearest neighbour matching (NNM) with replacement and Kernel matching (KM) are employed to select the most appropriate matching method.

Table 16. Matching performance of matching methods

\begin{tabular}{lccc}
\hline $\begin{array}{l}\text { Matching } \\
\text { methods }\end{array}$ & $\begin{array}{c}\text { Number of explanatory variables with } \\
\text { insignificant mean between the match of } \\
\text { contracted and independent farmers }\end{array}$ & Pseudo $\mathbf{R}^{2}$ & $\begin{array}{c}\text { Matched } \\
\text { sample } \\
\text { size }\end{array}$ \\
\hline NNM & 5 & 0.033 & 334 \\
NNM(1) & 5 & 0.029 & 334 \\
NNM(2) & 7 & 0.018 & 334 \\
NNM(3) & 7 & 0.011 & 334 \\
$\mathrm{NNM}(4)$ & 7 & 0.007 & 334 \\
$\mathrm{NNM}(5)$ & & & \\
$\mathrm{KM}$ & 6 & 0.011 & 334 \\
$\mathrm{KM}(0.1)$ & 6 & 0.017 & 334 \\
$\mathrm{KM}(0.25)$ & 1 & 0.067 & 334 \\
$\mathrm{KM}(0.5)$ & & & \\
\hline
\end{tabular}

Source: Author's calculation.

Note: Numbers in parentheses denote the number of neighbor estimators in the NNM and bandwidth in the KM.

Matching methods are chosen if they have all the explanatory variables with insignificant mean between the match of contracted and independent farmers, the lowest pseudo $\mathrm{R}^{2}$, and the largest matched sample size (Tsadik and others, 2015; Mulatu and others, 2017). In that case, the most appropriate matching method is the $\mathrm{NNM}(5)$ because it has all the insignificant explanatory variables, the lowest pseudo $R^{2}(0.007)$, and the largest matched sample size. Thus, only the NNM(5) is selected to estimate impacts of contract farming on tea productivity in this research (table 16). 


\section{Assessment on the match quality}

To examine the match quality of the NNM(5), means of the propensity score and explanatory variables are estimated and compared before and after matching. Results of testing the propensity score and explanatory variables for the NNM(5) are presented in table 17.

Table 17. Propensity scores and covariate balancing for the NNM(5)

\begin{tabular}{|c|c|c|c|c|c|c|c|}
\hline \multirow[b]{2}{*}{ Variables } & \multirow[b]{2}{*}{ Sample } & \multicolumn{2}{|c|}{ Mean } & \multicolumn{2}{|c|}{$\begin{array}{l}\text { Per cent bias } \\
\text { reduction }\end{array}$} & \multicolumn{2}{|c|}{ T-test } \\
\hline & & Treated & Control & $\begin{array}{l}\text { Per } \\
\text { cent } \\
\text { bias }\end{array}$ & |bias| & $\mathbf{t}$ & p-value \\
\hline \multirow[t]{2}{*}{ Pscore } & Unmatched & 0.631 & 0.351 & 125.3 & & 11.45 & 0.000 \\
\hline & Matched & 0.631 & 0.623 & 3.7 & 97.0 & 0.35 & 0.729 \\
\hline \multirow[t]{2}{*}{ Age } & Unmatched & 48.399 & 48.754 & -3.7 & & -0.33 & 0.739 \\
\hline & Matched & 48.399 & 47.666 & 7.5 & -106.0 & 0.65 & 0.518 \\
\hline \multirow[t]{2}{*}{ Gender } & Unmatched & 0.957 & 0.847 & 37.3 & & 3.39 & 0.001 \\
\hline & Matched & 0.957 & 0.938 & 6.3 & 83.1 & 0.75 & 0.456 \\
\hline Household & Unmatched & 0.036 & 0.169 & -44.6 & & -4.04 & 0.000 \\
\hline categories & Matched & 0.036 & 0.039 & -0.8 & 98.2 & -0.12 & 0.908 \\
\hline \multirow[t]{2}{*}{ Family labourers } & Unmatched & 3.018 & 2.526 & 47.1 & & 4.30 & 0.000 \\
\hline & Matched & 3.018 & 3.078 & -5.8 & 87.8 & -0.46 & 0.642 \\
\hline \multirow[t]{2}{*}{ Land size for tea } & Unmatched & 22.715 & 17.139 & 36.1 & & 3.31 & 0.001 \\
\hline & Matched & 22.715 & 22.28 & 2.8 & 92.2 & 0.24 & 0.807 \\
\hline \multirow[t]{2}{*}{ Tea age } & Unmatched & 17.791 & 22.257 & -47.8 & & -4.37 & 0.000 \\
\hline & Matched & 17.791 & 18.622 & -8.9 & 81.4 & -0.86 & 0.390 \\
\hline \multirow[t]{2}{*}{ Density } & Unmatched & 604.36 & 516.9 & 83.8 & & 7.63 & 0.000 \\
\hline & Matched & 604.36 & 606.64 & -2.2 & 97.4 & -0.18 & 0.858 \\
\hline
\end{tabular}

Source: Author's calculation.

Before matching, all covariates exhibit statistically significant differences, except age. However, after matching, covariates are balanced. The insignificant likelihood ratio tests of all covariates imply that the matching procedure is able to balance the characteristics in the treated group (contracted farmers) and the control group (independent farmers) (table 17).

Quality of matching methods is presented in table 18. 
Table 18. Quality of matching methods before and after matching

\begin{tabular}{|c|c|c|c|c|c|c|c|}
\hline \multirow{2}{*}{$\begin{array}{l}\text { Matching } \\
\text { methods }\end{array}$} & \multicolumn{3}{|c|}{ Before matching } & \multicolumn{3}{|c|}{ After matching } & \multirow{2}{*}{$\begin{array}{c}\text { Total } \\
\text { bias } \\
\text { reduction } \\
(\%)\end{array}$} \\
\hline & $\begin{array}{c}\text { Pseudo } \\
\mathbf{R}^{2}\end{array}$ & $\begin{array}{l}\text { LRchi2 } \\
\text { (p-value) }\end{array}$ & $\begin{array}{c}\text { Mean } \\
\text { bias }\end{array}$ & $\begin{array}{c}\text { Pseudo } \\
\mathbf{R}^{2}\end{array}$ & $\begin{array}{l}\text { LRchi2 } \\
\text { (p-value) }\end{array}$ & $\begin{array}{l}\text { Mean } \\
\text { bias }\end{array}$ & \\
\hline NNM(5) & 0.227 & $\begin{array}{l}105.00 \\
(0.000)\end{array}$ & 53.2 & 0.008 & $\begin{array}{c}3.65 \\
(0.887)\end{array}$ & 4.8 & 50 \\
\hline
\end{tabular}

Source: Author's calculation.

Low pseudo $\mathrm{R}^{2}$ and the insignificant likelihood ratio tests reflect that treatment and control groups have the same distribution in covariates after matching and that matching methods can balance characteristics of the treated and control groups (Wainaina and others, 2012; Chege and others, 2015; and Huluka and Negatu, 2016). After matching, pseudo $R^{2}$ dropped from 0.227 to 0.008 , the likelihood ratio is insignificant (0.887), and total bias decreased by 50 per cent. Accordingly, the $\mathrm{NNM}(5)$ can be employed to estimate the influence of contract participation on tea productivity (table 18).

Estimation of average treatment effects on the treated (ATT) for tea productivity

Results of ATT estimation are presented in table 19.

Table 19. Estimation of ATT for tea productivity

\begin{tabular}{lcccc}
\hline Matching methods & $\begin{array}{c}\text { Unmatched and } \\
\text { ATT }\end{array}$ & Difference & Standard Error & T-stat \\
\hline NNM(5) & Unmatched & 4781.76 & 902.66 & 5.30 \\
& ATT & 3996.92 & 1272.38 & 3.14 \\
\hline
\end{tabular}

Source: Author's calculation.

The ATT value accounts for 3,997 ; this implies that tea productivity of contracted households is higher than that of independent ones by $3,997 \mathrm{~kg} / \mathrm{year}$ (or 3.99 tons/ year).

Implementation of sensitivity analysis

The Rosenbaum bounds (rbounds test) is used to test the presence of hidden bias due to unobserved covariates for the NNM(5). 
Table 20. Results of the sensitivity analysis for the hidden bias

\begin{tabular}{ccc}
\hline Gamma & Sig + & Sig- \\
\hline 1 & 0 & 0 \\
2 & 0 & 0 \\
3 & 0 & 0 \\
4 & $1.2 \mathrm{e}-15$ & 0 \\
5 & $7.0 \mathrm{e}-13$ & 0 \\
6 & $5.0 \mathrm{e}-11$ & 0 \\
7 & $1.1 \mathrm{e}-09$ & 0 \\
8 & $1.1 \mathrm{e}-08$ & 0 \\
9 & $6.5 \mathrm{e}-08$ & 0 \\
10 & $2.7 \mathrm{e}-07$ & 0 \\
\hline
\end{tabular}

Source: Author's calculation.

Note: Gamma presents log odds of differential assignment due to unobserved factors Sig+ means upper bound significance level

Sig- means lower bound significance level

The results show that the $p$-critical values of all outcome variables estimated at various level of critical values of gamma are significant, which implies that important covariates affecting the participation and outcome variables have been considered. The ATT is insensitive to unobserved selection bias and accordingly, it can be conclude that there is a pure effect of the participation on contract farming of tea production (table 20).

\section{CONCLUSION AND POLICY IMPLICATIONS}

The objective of the present paper is to estimate determinants affecting tea productivity and investigate the impacts of contract participation on tea productivity in the rural area of Viet Nam, such as Phu Tho province. The results show that the influence of determinants on tea productivity varies in different models. It can be concluded that land size is statistically significant and positively affects tea productivity of both contract and independent farmers. It also indicates that pesticide costs present a positive relationship with the tea productivity of contracted households, capital is statistically significant and has a positive impact on tea productivity of independent households and that density has a negative influence on tea productivity of both contracted and independent farmers. 
Based on the estimation from the study, the technical efficiency of tea production for contracted farmers is 59.9 per cent, while for independent households, it is 55.1 per cent. The results indicate that technical efficiency of contracted farmers is higher than that of their counterparts by 4.8 per cent. This outcome is derived from the more favourable conditions extended to contracted farmers to participate in the contract. For example, contracted producers purchase fertilizers and pesticides with adequate quality and at reasonable prices in addition to receiving technical assistance provided by contractors.

The results show that the difference in tea productivity between contracted and independent households is 3.9 tons a year. Those outcomes reflect the positive influence of contract farming on tea productivity in Phu Tho province.

Some recommendations for Government and Phu Tho province to enhance tea productivity and reduce poverty for farm households are the following. First, policies set by Government and Phu Tho province should be consistent with the factors that either positively or negatively influence tea productivity. For example, land size positively affects tea productivity. Based on that, the policies should focus on solving constraints related to increasing land area. The average planted area for tea of a household in Phu Tho province ranges from 0.6 hectares to 0.8 hectares, areas that are too small for tea cultivation. This can be overcome if the Government and Phu Tho province were to establish production zones for tea plantation and facilitate land concentration by expanding the land quota to 30 hectares for tea producers in the midlands and mountainous areas based on the regulation of the Land Law issued in 2013. In contrast, tea density presents a negative effect on tea productivity, which suggests that tea productivity may decline if farmers plant more tea trees in an area. Currently, producers plant about 555 trees a sao; this density level should be retained to avoid a decline in tea productivity. Second, technical innovations in tea production should be researched and adopted to reduce technical inefficiency of tea production. Specifically, technical inefficiency of contracted and independent farmers is 40 per cent and 45 per cent, respectively. Advanced technologies in varieties, fertilizer and chemical applications, harvested techniques, and irrigation should be considered by agricultural scientists and extension experts. For example, old tea varieties should be substituted by new and better quality varieties, such as LDP1, LDP2, Kim Tuyen, and PH1. Also, in addition to setting new procedures for producing and processing tea, building sustainable relationships between tea producers and contractors through contract farming should be encouraged. Finally, contract participation positively affects tea productivity. However, the increase in tea productivity should take into account the volatility associated with production inputs, such as fertilizers and pesticides, because a rise in tea productivity would not improve income and the livelihood of tea growers if output prices are low and the profits do not compensate the increase expenditure for production inputs. 
The major limitation of the study is that the sample is not nationally representative. Because of differences in climatic condition in Viet Nam, the results from this study are not generalizable across the country. The findings can, however, be applied in the Northern midlands and mountainous areas, which have similar climate, land characteristics and production patterns. As the data gathered for this study are cross-sectional, they do not show causality and association of tea yield. Further studies should, therefore, be conducted to reduce the limitations of this research, which are as follows. This study only focuses on assessing impacts of contract farming on tea productivity, and ignores the effects of contract farming on social and cultural aspects, such as employment, production habits and family relationships. In addition, it is very difficult to estimate accurately the influence of contract farming on tea productivity because of the effects of unobservable determinants, such as weather and managerial ability of farmers. Finally, in addition to estimation of tea productivity, the volatility of input prices, such as fertilizers and chemicals, should be considered to ensure profitability of farmers in the long term. 


\section{REFERENCES}

ActionAid (2015). Contract farming and out-grower schemes: appropriate development models to tackle poverty and hunger? Policy Discussion Paper, March 2015. Johannesburg: ActionAid.

Ajao, A. O., and G. A. Oyedele (2013). Economic efficiency of contract farming in Oyo state: experience from British American Tobacco Company. International Journal of AgriScience, vol. 3, No. 9, pp. 699-707.

Ali, Akhter, and others (2013). Determinants of cherry production and marketing in Pakistan: a propensity score matching approach. Agricultural Economic Review, vol. 14, No. 1, pp. 45-58.

Baker, Judy L. (2000). Evaluating the Impact of Development Projects on Poverty: A Handbook for Practitioners. Directions in Development. Washington, D.C.: World Bank.

Begum, Ismat A., and others (2012). Contract farmer and poultry farm efficiency in Bangladesh: A data envelopment analysis. Applied Economics, vol. 44, No. 28, pp. 3737-3747.

Bellemare, Marc F. (2012). As you sow, so shall you reap: the welfare impacts of contract farming. World Development, vol. 40, No. 7, pp. 1418-1434. DOI: 10.1016/j.worlddev.2011.12.008.

Birthal, Pratap S., and others (2008). Improving farm-to-market linkages through contract farming: a case study of smallholder dairying in India. IFPRI Discussion Paper 00814. Washington, D.C.: International Food Policy Research Institute.

Bravo-Ureta, Boris, William H. Greene, and Daniel Solis (2012). Technical efficiency analysis correcting for biases from observed and unobserved variables: an application to a natural resource management project. Empirical Economics, vol. 43, No. 1, pp. 55-72.

Chege, Jane Wambui, and others (2015). Impact of export horticulture farming on per capita calorie intake of smallholder farmers in Eastern and Central provinces in Kenya. International Journal of Food and Agricultural Economics, vol. 3, No. 4, pp. 65-81.

Coelli, Timothy J., and others (2005). An Introduction to Efficiency and Productivity Analysis. New York: Springer.

Daniel, Wayne W., and Chad L. Cross (2013). Biostatistics: A Foundation for Analysis in the Health Sciences. Tenth edition. John Wiley \& Sons, Inc, 2013.

Department of Agriculture and Rural Development in Phu Tho province (2015). Report on Tea Production in 2015 and the Direction for Tea Development In 2016 (Vietnamese).

Food and Agriculture Organization of the United Nations (FAO) (2018). FAOSTAT, Macro Indicators Database. Available from www.fao.org/faostat/en/\#data/MK. Accessed 12 February 2018. (2018). FAOSTAT, Suite of Food Security Indicators Database. Available from www. fao.org/faostat/en/\#data/FS. Accessed 9 February 2018.

Gemici, Sinan, Jay W. Rojewski, and Heok Lee (2012). Use of propensity score matching for training research with observational data. International Journal of Training Research, vol. 10 , No. 3, pp. 219-232.

General Statistics Office of Vietnam (2015). Statistical Yearbook of Viet Nam 2014. Hanoi: Statistical Publishing House. Available from www.gso.gov.vn/default_en.aspx?tabid=515\&idmid= \&ltemID=15197. Accessed 9 February 2018. 
General Statistics Office of Vietnam (2018). The Rate of Poor Households by Regions and Provinces in Viet Nam. Available from https://www.gso.gov.vn/Default_en.aspx?tabid=723. Accessed 9 February 2018.

Greene, William (2010). A stochastic frontier model with correction for sample selection. Journal of Productivity Analysis, vol. 34, No. 1, pp. 15-24.

Hassan, Sarfraz, and Bashir Ahmad (2005). Stochastic frontier production function: Application and hypothesis testing. International Journal of Agriculture \& Biology, vol. 7, No. 3, pp. 427-430.

Heckman, James J. (1979). Statistical Models for Discrete Panel Data. Chicago, IL: Department of Economics and Graduate School of Business, University of Chicago.

Heckman, James J., Hidehiko Ichimura, and Petra Todd (1998). Matching as an econometric evaluation estimator. The Review of Economic Studies, vol. 65, No. 2, pp. 261-294.

Henningsen, Arne, and others (2015). The effects of contract farming on efficiency and productivity of small-scale sunflower farmers in Tanzania. Twenty-ninth International Conference of Agricultural Economists. Milan, Italy. 8-14 August, 2015.

Huluka, Admassu Tesso, and Workneh Negatu (2016). The impacts of farmer field school training on knowledge and farm technology adoption: evidence from smallholder maize farmers in Oromia, Ethiopia. Journal of Economics and Public Finance, vol. 2, No. 1, pp. 1-21.

Kalimangasi, Nathaniel Naftali, Agrey Kihombo, and Natalia Kalimang'asi (2014). Contribution of contract cocoa production on improving livelihood of smallholder farmers. International Journal of Scientific and Research Publications, vol. 4, No. 10, pp. 1-10.

Key, Nigel (2013). Production contracts and farm business growth and survival. Journal of Agricultural and Applied Economics, vol. 45, No. 2, pp. 277-293.

Khoi, Nguyen Viet, Chu Huong Lan, and To Linh Huong (2015). Vietnam tea industry: an analysis from value chain approach. International Journal of Managing Value and Supply Chains (IJMVSC), vol. 6, No. 3, pp. 1-15.

Kumar, Anjani, and others (2016). Impact of contract farming on profits and yield of smallholder farms in Nepal: an evidence from lentil cultivation. Paper prepared for presentation at the 2016 Agricultural and Applied Economics Association Annual Meeting, Boston, Massachusetts, 31 July-2 August 2016.

Leuven, Edwin, and Barbara Sianesi (2003). PSMATCH2: Stata module to perform full Mahalanobis and propensity score matching, common support graphing, and covariate imbalance testing, version. [computer software]. Boston, MA: Boston College.

Meshesha, Jony Girma (2011). Impact of contract farming on household income of smallholder farmers: the case of organic honey production in South West Ethiopia, Sheka zone. Thesis submitted to the Wageningen University and Research Centre. Available from http://edepot.wur.nl/193737.

Miyata, Sachiko, Nicholas Minot, and Dinghuan Hu (2009). Impact of contract farming on income: linking small farmers, packers, and supermarkets in China. World Development, vol. 37, No. 11 , pp. 1781-1790.

Mulatu, Gemechu, and others (2017). Impact of participation in vegetables' contract farming on household's income in the Central Rift valley of Ethiopia. American Journal of Rural Development, vol. 5, No. 4, 90-96. DOI: 10.12691/ajrd-5-4-1. Available from http://pubs. sciepub.com/ajrd/5/4/1. 
Ngoc, Nguyen Thi Bich, Ho Van Bac, and Nguyen Thuong Huyen (2014). Comparative analysis of non-contract and contract farmers in tea sector in Vietnam: the case study in Thai Nguyen and Phu Tho provinces. Journal of Science \& Technology, vol. 119, No. 5, pp. 143-149.

Paul, Catherine J., Richard Nehring, and David Banker (2004). Productivity, economies, and efficiency in U.S. agriculture: a look at contracts. American Journal of Agricultural Economics, vol. 86, No. 5, pp. 1308-1314.

Phu Tho Statistics Office (2017). Statistical Handbook of Phu Tho 2017. Available from http:// online.flipbuilder.com/nwzs/nzqc/mobile/index.html.

Ramaswami, Bharat, Pratap Singh Birthal, and Pramod Kumar Joshi. (2005). Efficiency and distribution in contract farming: the case of Indian poultry growers. MTID Discussion Paper. No. 91. IFPRI. Washington, D.C.

Rosenbaum, Paul R., and Donald B. Rubin (1983). The central role of the propensity score in observational studies for causal effects. Biometrika, vol. 70, No. 1, pp. 41-55.

Saigenji, Yoshiko, and Manfred Zeller (2009). Effect of contract farming on productivity and income of small holders: the case of tea production in north-western Vietnam. Paper prepared for presentation at the International Association of Agricultural Economists Conference, Beijing, China. 16-22 August 2009. Available from www.researchgate.net/ publication/228542523_Effect_of_contract_farming_on_productivity_and_income_of_ small_holders_The_case_of_tea_production_in_north-western_Vietnam.

Setboonsarng, Sununtar, PingSun Leung, and Adam Stefan (2008). Rice contract farming in Lao PDR: moving from subsistence to commercial agriculture. ADB Institute Discussion Paper No. 90. Tokyo: ADBI.

Tsadik, Ermias T., Berhan Tamir, and Zemelak Sahile (2015). The impact of village poultry technology adoption on the livelihood of smallholder farmers in the Central Oromia region, Ethiopia. Journal of Animal Production Advances, vol. 5, No. 11, pp. 807-819.

United Nations (2016). Country programme document for Viet Nam. Country programme and related matters. Executive Board of the United Nations Development Programme, the United Nations Population Fund and the United Nations Office for Project Services, the United Nations. DP/DCP/VNM/2. 8 July 2016. Available from www.vn.undp.org/content/ vietnam/en/home/library/democratic_governance/country-programme-document-forviet-nam-2017-2021.html.

Velde, Katrien Vande, and Miet Maertens (2014). Impact of contract-farming in staple food chains: the case of rice in Benin. Paper prepared for presentation at the EAAE 2014 Congress Agri-Food and Rural Innovation for Healthier Societies, Ljublijana, 26-29 August 2014. Available from https://ageconsearch.umn.edu/record/182682/files/Vande_Velde-Impact_ of_contract-farming_in_staple_food_chains-521_a.pdf.

Wainaina, Priscilla W., Julius Juma Okello, and Jonathan M. Nzuma (2012). Impact of contract farming on smallholder poultry farmers' income in Kenya. Paper prepared for presentation at the International Association of Agricultural Economists (IAAE) Triennial Conference, Foz do Iguacu, Brazil, 18-24 August, 2012. Available from https://www.researchgate. net/publication/254387514_Impact_of_Contract_Farming_on_Smallholder_Poultry_ Farmer\%27_Income_in_Kenya. 